\title{
OPTIMALISASI KONSEP REWARD TERHADAP WHISTLE BLOWER TINDAK PIDANA KORUPSI DI INDONESIA
}

\author{
Edi As'adi \\ Program Doktor Ilmu Hukum Universitas Diponegoro, \\ J1. Imam Bardjo,SH No.1 Semarang, \\ Email: edi_45401@yahoo.co.id
}

\begin{abstract}
Looking at the contents of Article 10 paragraph (2) there are two interesting conclusions: (1) Whistle blower remains liable if it is proven legally and convincingly guilty based on the principle oflegality. A whistle blower only get reward in the form of relief in the form of restorative justice is not a criminal. This is obviously not the reward that reflects the principles defined in Article 3 of Law 13 of 2006 that the principle of respect for human dignity, the principles of justice and legal certainty. The testimony of whistle blower not only just be considered by a judge but should be a consideration of the reward is commensurate with the information given to reveal the corruption.
\end{abstract}

Keywords: Reward; Whistle Blower; Corruption.

\begin{abstract}
Abstrak
Mencermati rumusan Pasal 10 ayat (2) ada dua kesimpulan yang menarik, yaitu (1) Whistle blower tetap dipidana bila ternyata terbukti secara sah dan meyakinkan bersalah berdasarkan asas legalitas. Whistle blower hanya mendapatkan reward berupa keringanan pidana bukan berupa restorative justice. Hal ini belum mencerminkan azas-azas yang telah ditentukan di dalam Pasal 3 Undang-Undang No.13 Tahun 2006 yakni azas penghargaan atas harkat dan martabat manusia, azas keadilan dan azas kepastian hukum. Seharusnya kesaksian dari Whistle blower bukan lagi hanya dipertimbangkan oleh hakim namun harus menjadi pertimbangan pemberian reward yang sepadan dengan keterangan yang diberikan untukmengungkap tindak pidana korupsi.
\end{abstract}

Kata Kunci : Penghargaan; Whistle Blower; Korupsi.

\section{A. Pendahuluan}

Istilah whistle blower dalam konteks bahasa Indonesia berarti peniup peluit, yang mana istilah ini sering menjadi perdebatan hangat, terlebih ketika berbagai media massa, baik elektronik maupun cetak mengabarkan berbagai peristiwa tindak pidana korupsi dan pencucian uang. Mencermati fenomena semacam itu, maka sudah selazimnya dalam rangka mengungkap lebih banyak kasus tindak pidana korupsi dan tindak pidana pencucian uang, menurut Jurgen Habermas setiap individu diberikan ruang (sphere) untuk berkomunikasi yang bersifat emansipatoris berorientasi menyelamatkan individu whistle blower tersebut dari ancaman yang dapat membahayakan keselamatannya serta keluarganya. Serta menyelamatkan kekayaan negara dari tangantangan para koruptor. Terkait hal itu, Satjipto Rahardjo menyampaikan, bahwa keinginan untuk memberantas korupsi bukan hal baru, bukan ditandai garis start 27 Desember 2002, tetapi sudah sejak 1970-an, lebih dari 30 tahun. Lalu, mengapa para terdakwa koruptor harus menikmati kelonggaran release and discharge? Perdebatan tentang penggunaan asas retroaktif tidak menyentuh substansi karena sudah lebih dari 30 tahun kita ingin melakukan pemberantasan korupsi yang kini semakin parah.

Jadi, yang dihadapi dalam kontroversi penggunaan asas retroaktif sebenarnya tidak menyangkut hal substansial. Penggunaan asas retroaktif memang bisa menjadi masalah besar jika kita memproyeksikannya pada latar 
belakang alam pikiran hukum liberal. Di situ asas nonretroaktif menjadi salah satu pilar penting untuk mengamankan bastion perlindungan individu. Untuk itu, prosedur menjadi andalan.Dalam suasana serba luar biasa ini, marilah kita bertindak progresif dengan berani membebaskan diri dari dominasi teknikalitas, prosedur, doktrin, serta asas konvensional, jika itu membelenggu kita untuk keluar dari penderitaan. ${ }^{1}$

Beberapa kasus korupsi di antaranya kasus Gayus Halauman Tambunan, Susno Duaji, Kasus Anggodo dan Nazaruddin, Angelina Sondah dan lain-lain, dari kasuskasus korupsi tersebut muncul satu keinginan dari publik yang menginginkan agar mereka tersangka pelaku tindak pidana korupsi atau pencucian uang mendapatkan reward bila mereka berani blak-blakan mengungkap dan menyebut para oknum pejabat di tingkat 'penegak hukum' hingga pejabat negara yang terlibat di dalam skandal tindak pidana korupsi. Bila hal ini dapat terjadi memang upaya pemerintah melakukan pemberantasan tindak pidana korupsi dapat mencapai keberhasilannya, yang setidaknya mendekati keberhasilannya.

Masalah yang timbul adalah sejauh manakah perlindungan dan kepastian hukum yang diberikan oleh Lembaga Perlindungan Saksi dan Korban kepada whistle blower yang berani mengungkap secara terang oknum-oknum yang terlibat di dalam tindak pidana korupsi? Bagaimana implementasi pemberian reward kepada whistle blower dalam tindak pidana korupsi? Bagaimana rekonstruksi konsep perlindungan saksi dan korban terhadap whistle blower di masa depan?

\section{B. Pembahasan}

Dasar falsafah negara adalah Pancasila termuat dalam Pembukaan Undang-Undang
Dasar 1945 dan seluruh batang tubuhnya sebagai landasan konstitusional negara. Salah satu pilar Grand Design Sistem dan Politik Hukum Nasional adalah prinsip bahwa hukum mengabdi pada kepentingan bangsa untuk memajukan negara dan menjadi pilar demokrasi dan tercapainya kesejahteraaan rakyat. $^{2}$

Hukum berfungsi sebagai alat dan cermin budaya masyarakat, alat untuk menegakkan ketertiban yang sifatnya konservatif (memelihara) serta alat untuk membangun (mengarahkan) masyarakat agar lebih maju. ${ }^{3}$ Dengan demikian produk hukum yang dihasilkan merupakan hukum yang konsisten dengan falsafah Negara, mengalir dari landasan Undang-Undang Dasar Negara RI 1945 dan secara sosiologis menjadi sarana untuk tercapainya keadilan dan ketertiban masyarakat serta harus mencerminkan aspek filosofis, yuridis, sosiologis dan historis sehingga kehidupan bangsa dan negara harus berkesinambungan. ${ }^{4}$

Mengingat tujuan negara Indonesia yang termaktub di dalam pembukaan UUD 1945 alinea keempat yang salah satunya adalah melindungi segenap bangsa Indonesia dan seluruh tumpah darah Indonesia dan untuk memajukan kesejahteraan umum. Apabila dilihat dalam kalimat "melindungi dan memajukan kesejahteraan umum" dapat disinyalir bahwa sesungguhnya Negara Indonesia harus dapat melindungi dan mensejahterakan seluruh rakyat Indonesia tanpa diskriminasi ras, agama, pendidikan, dan latar belakang sosial lainnya. Lahirnya Undang-Undang No. 8 Tahun 2010 Tentang Pencegahan Dan Pemberantasan Tindak Pidana Pencucian Uang (selanjutnya akan ditulis UU TPPU), merupakan paradigma baru dalam mencegah dan memberantas kejahatan, melalui prinsip follow the money, yaitu mengikuti uang hasil kejahatan yang disamarkan untuk dijadikan-seolah-

1. Tersedia di website http://www.kompas.com/kompas-cetak/0503/01/opini/1592610.htm, diakses pada tanggal 12 Juni 2013.

2. Barda Nawawi Arief, 2009, Reformasi Sistem Peradilan (sistem Penegakan Hukum) di Indonesia, Semarang, Badan Penerbit Universitas Diponegoro, hlm 133-134

3. Mochtar Kusumaatmadja, 2002, Konsep-Konsep Hukum dalam Pembangunan, Pusat Studi Wawasan Nusantara, Hukum dan Pembangunan, Bandung, PT Alumni, hlm 13-14

4. Barda Nawawi Arief, 2001, Masalah Penegakan Hukum dan Kebijakan Penanggulangan Kejahatan, Bandung, PT. Citra Aditya Bakti, hlm 27. 
olah-uang hasil yang sah, mudah untuk dideteksi dan ditelusuri, bahkan sampai pada aktor intelektualnya. Sudah sangat dikenal oleh awam bahwa korupsi merupakan kejahatan yang merugikan keuangan negara. Fakta senyatanya lebih luas, bahwa korupsi merupakan perbuatan bejat, busuk, jahat, jelek, tidak jujur, dan konotasi negatif lainnya, bahkan extra ordinary crime. Dengan demikian pengertian, lingkup, dan bentuk korupsi dapat ditelisik secara harfiah, yuridis, sosiologis, politis, dan sebagainya. ${ }^{6}$

Dalam perkembangan sekarang ini, penanganan terhadap tindak pidana korupsi juga dapat dilakukan melalui whistle blower. Model reward terhadap whistle blower pada dasarnya merupakan upaya pembaharuan hukum pidana, yaitu suatu Pembaharuan hukum pidana pada hakekatnya mengandung makna, suatu upaya untuk melakukan reorientasi dan reformasi hukum pidana yang sesuai dengan nilai-nilai sentral sosio-politik, sosio-filosofik, dan sosio-kultural masyarakat Indonesia yang melandasi kebijakan sosial, kebijakan kriminal, dan kebijakan penegakkan hukum di Indonesia, ${ }^{7}$ khususnya hukum pidana (penal reform).

Perlindungan hukum dan kepastian hukum ini seharusnya (das Sollen) merupakan suatu yang essensial diberikan kepada seluruh masyarakat Indonesia dengan tidak terkecuali termasuk whistle blower tindak pidana korupsi, sesuai amanah konstitusi yang terumus di dalam Pasal 27 ayat (1) Undang-Undang Dasar Negara RI Tahun 1945 juga menyebutkan bahwa segala warga negara bersamaan kedudukannya di dalam hukum dan pemerintahan dan wajib menjunjung hukum dan pemerintahan itu dengan tidak ada kecualinya. Artinya sesuai dengan prinsip azas equality before the law. Selanjutnya, dalam Pasal 28D ayat (1) landasan Undang-Undang Dasar Negara RI Tahun 1945, kedudukan whistle blower juga sangat diperhatikan oleh konstitusi terungkap dengan kalimat yang berbunyi setiap orang berhak atas pengakuan, jaminan, perlindungan dan kepastian hukum yang adil serta perlakuan yang sama di hadapan hukum. Artinya, bahwa setiap orang di sini adalah juga termasuk whistle blower dalam tindak pidana korupsi.

Perlindungan dan kepastian hukum yang wajib diberikan oleh negara bukan hanya terhadap whistle blower saja, tetapi seluruh kerabat keluarganya, sebagaimana yang tertulis di dalam Undang-Undang Dasar Negara RI Tahun 1945 menyebutkan bahwa: (1) Setiap orang berhak atas perlindungan diri pribadi, keluarga, kehormatan, martabat, dan harta benada yang di bawah kekuasaannya serta berhak atas rasa aman dan perlindungan dari ancaman ketakutan untuk berbuat atau tidak berbuat sesuatu yang merupakan hak asasi; (2) setiap orang berhak untuk bebas dari penyiksaan atau perlakuan yang merendahkan derajad martabat manusia dan berhak memperoleh suaka politik dari negara lain.

Secara normatif, whistle blower yang bila direlevansikan terhadap proses sistem peradilan (substansi dan struktur hukum) dalam penegakan hukum yaitu mulai dari penyelidikan, penyidikan, penuntutan dan pemeriksaan di pengadilan hingga pelaksanaan eksekusi adalah memiliki kedudukan yang sangat berarti dalam mengungkap tindak pidana korupsi yaitu sebagai saksi, berdasarkan azas praduga tak bersalah (presumtion of innocent). Kedudukan whistle blower sebagai saksi ini seharusnya (das Sollen) juga telah diakui oleh Undang-Undang, yaitu terbukti pada rumusan Pasal 1 ayat (1) Undang-Undang No. 13 Tahun 2006 tentang Perlindungan Saksi dan Korban (selanjutnya disebut Undang-Undang No. 13 Tahun 2006), yang menyebutkan bahwa Saksi adalah orang yang dapat memberikan keterangan guna kepentingan penyelidikan, penyidikan, penuntutan, dan pemeriksaan di sidang pengadilan tentang suatu perkara yang ia dengan sendiri, ia lihat sendiri, dan atau ia alami sendiri.

Model Reward ini secara ideal benarbenar menghargai eksistensi whistle blower yaitu diberikannya perlindungan dari suatu

\footnotetext{
5. Halif, "Pencegahan dan Pemberantasan Tindak Pidana Korupsi Melalui Undang-Undang Pencucian Uang", Jurnal Anti Korupsi PUKAT FHUJ, Vol.2, No. 2, November 2012, hlm 70.

6.Bambang Waluyo, “Optimalisasi Pemberantasan Kurupsi Di Indonesia”, Jurnal Yuridis, Vol. 1, No. 2, Desember 2014, ISSN 1693448, hlm. 169 - 182

7. Barda Nawawi Arief, 2001, Op. Cit, hlm 27
} 
tindakan suatu ancaman berupa segala bentuk perbuatan yang menimbulkan akibat, baik langsung maupun tidak langsung yang mengakibatkan saksi merasa takut dan atau dipaksa untuk melakukan atau tidak melakukan sesuatu hal yang berkenaan dengan pemberian kesaksiannya dalam suatu proses peradilan pidana, demikian yang diatur di dalam Pasal 1 ayat (4) Undang-Undang No. 13 Tahun 2006

Jaminan perlindungan hukum sebagai suatu model reward tidak hanya diberikan kepada whistle blower, namun Negara melalui rumusan Pasal 1 ayat (5) Undang-Undang No. 13 Tahun 2006, juga memberikan perlindungan kepada keluarganya yaitu orang yang mempunyai hubungan darah dalam garis lurus ke atas atau ke bawah dan garis menyamping sampai derajat ketiga, atau orang yang menjadi tanggung jawab Saksi adan atau Korban. Selanjutnya, perlindungan dimaksud oleh Pasal 1 ayat (6) UndangUndang No.13 Tahun 2006 adalah segala upaya pemenuhan hak dan pemberian bantuan untuk memberikan rasa aman kepada Saksi dan Korban yang wajib dilaksanakan oleh LPSK atau lembaga lainnya sesuai dengan ketentuan Undang-undang ini. baik diri pribadinya dan atau keluarganya, oleh karena itu wajib diberikan perlindangan lahir maupun bathin yang dapat memberikan rasa aman kepada Saksi (whistle blower) dalam memberikan keterangan pada setiap proses peradilan pidana. Ketentuan normatif perlindungan terhadap whistle blower ini memang sangat berarti dalam upaya mengungkap tindak pidana khususnya tindak pidana korupsi.

Batasan perlindungan terhadap whistle blower secara garis besar telah dirumuskan di dalam ketentuan Pasal 5 ayat (1) UndangUndang No. 13 Tahun 2006, yaitu bahwa Saksi dan Korban berhak:

a. Memperoleh perlindungan atas keamanan pribadi, keluarga, dan harta bendanya, serta bebas dari ancaman yang berkenaan dengan kesaksiannya yang akan, sedang, atau telah diberikannya;

b. Ikut serta dalam proses memilih dan menentukan bentuk perlindungan dan dukungan keamanan; c. Memberikan tanpa tekanan;

d. Mendapat penerjemah

e. Bebas dari pertanyaan yang menjerat;

f. Mendapat informasi mengenai perkembangan kasus

g. Mendapat informasi mengenai putusan pengadilan

h. Mengetahui dalam hal terpidana dibebaskan

i. Mendapatidentitas baru

j. Mendapat tempat kediaman baru

k. Memperoleh penggantian biaya transportasi sesuai dengan kebutuhan

1. Mendapat nasihat hukum

m. Memperoleh bantuan biaya hidup sementara sampai pada batas waktu perlindungan berakhir.

Dari ke-13 hak perlindungan yang diberikan kepada whistle blower di atas menunjukkan bahwa seharusnya (das Sollen) upaya pemberantasan tindak pidana khususnya tindak pidana korupsi melalui optimalisasi kedudukan whistle blower akan menjadi semakin efektif, efisien dan mampu menciptakan kepastian dan perlindungan hukum yang tidak hanya bagi Whistle blower dan atau keluarganya saja, tetapi juga berguna untuk menciptakan kesejahteraan seluruh masyarakat.

Selain itu perwujudan reward yang diberikan oleh negara terhadap whistle blower secara normatif disebutkan di dalam rumusan Pasal 10 ayat (1) Undang-Undang No. 13 Tahun 2006 tentang Perlindungan Saksi dan Korban yang menyebutkan bahwa saksi, korban dan pelapor tidak dapat dituntut secara hukum baik pidana maupun perdata atas laporan, kesaksian yang akan, sedang atau telah diberikannya; inilah yang seharusnya menjadi dasar pemberian reward kepada mereka yang mau dengan sukarela membuka jalan untuk mengungkap tindak pidana korupsi dan tindak pidana pencucian uang (das Sollen). Pada sisi lain, dalam ayat (2) menyebutkan bahwa seorang saksi yang juga tersangka dalam kasus yang sama tidak dapat dibebaskan dari tuntutan pidana apabila ia ternyata terbukti secara sah dan meyakinkan bersalah, tetapi kesaksiannya dapat dijadikan pertimbangan hakim dalam 
meringankan pidana yang akan dijatuhkan. (garis bawah dari penulis).

Berdasarkan Pasal 10 ayat (2) di atas ada dua kesimpulan yang menarik, yaitu (1) Whistle blower tetap dipidana bila ternyata terbukti secara sah dan meyakinkan bersalah berdasarkan asas legalitas Pasal 1 ayat (1) dan ayat (2) KUHP, whistle blower hanya mendapatkan reward berupa keringanan pidana bukan berupa restorative justice. Hal ini jelas bukan reward yang mencerminkan azas-azas yang telah ditentukan di dalam Pasal 3 Undang-Undang No.13 Tahun 2006, yakni azas penghargaan atas harkat dan martabat manusia, azas keadilan dan azas kepastian hukum.

Semestinya apabila whistle blower, telah menyetujui untuk menandatangani perjanjian perlindungan dengan negara memalui LPSK terhadap dirinya sebagai Saksi seperti telah dirumuskan di dalam Pasal 28, Pasal 29, Pasal 30, Pasal 31, dan Pasal 32. Maka sudah semestinya kesaksian dari Whistle blower bukan lagi hanya dipertimbangkan oleh hakim namun harus menjadi pertimbangan pemberian reward yang sepadan dengan keterangan yang diberikan untuk mengungkap tindak pidana khususnya korupsi, sehingga diharapkan semua whistle blower akan merasa aman, terlindungi, mendapat keadilan dan kepastian yang tidak 'ngambang' sehingga mereka whistle blower tidak akan ragu lagi dalam membantu penegak hukum untuk menegakkan hukum yang sebenar-benarnya. Di Korea Selatan berani memberikan reward kepada whistle blower sebesar dua juta dollar Amerika Serikat), dan bahkan whistle blower mendapatkan perlindungan dan penghargaan yang istimewa dari negara karena jasajasanya tak ubahnya pahlawan yang telah berjasa menyelamatkan harta kekayaan negara yang dapat digunakan sebesarbesarnya untuk kemakmuran dan kesejahteraan seluruh masyarakat.

Whistle blower selain memiliki peran dalam membantu mengungkap suatu tindak pidana khususnya tindak pidana korupsi, juga dapat menjadi indikator bagi terwujudnya pelayanan administrasi sistem peradilan pidana dalam perspektif birokrasi penegakan hukum di Indonesia, yang selama ini dirasa masih karut marut dan rawan akan tindakan penyimpangan dan penyelewengan oleh oknum-oknum penegak hukum baik ditingkat penyelidikan, penyidikan, penuntutan, pemeriksaan dipengadilan dan pelaksanaan eksekusi.

Barda Nawawi Arif pernah mengingatkan dalam pernyataannya mengatakan bahwa bila dilihat dari aspek/komponen substansi hukum (legal substance) sistem peradilan pada hakekatnya merupakan sistem normatif atau sistem penegakan substansi hukum (merupakan integrated legal system atau integrated legal substance). Pada umumnya yang termasuk legal system (legal substance) di bidang peradilan/penegakan hukum, mencakup substansi hukum material, substansi hukum formal dan substansi hukum pelaksanaan eksekusi (execution law). ${ }^{8}$

Mencermati pendapat di atas mengisyaratkan bahwa sesungguhnya masih sangat diperlukan pembaharuan yang terkait dengan kedudukan whistle blower dalam setiap tindak pidana khususnya tindak pidana korupsi yaitu pada tataran substansi hukum material substansi hukum formalnya dan substansi pelaksanaan eksekusi yang berlandaskan nilai keadilan dalam menciptakan kesejahteraan masyarakat.

Uraian di atas membuktikan bahwa model Reward yang diberikan kepada whistle blower memiliki karakter hukum responsif dan progresif yang memiliki asumsi dasar bahwa hukum untuk manusia tanpa memandang ras, suku bangsa, agama, dan bahasa dan budaya, sehingga diharapkan apa yang dikatakan oleh Gustav Radbruch (19781949) tentang nilai dasar hukum sebagaimana dikutip Satjipto Rahardjo, mengemukakan tiga nilai dasar hukum ideal yaitu nilai dasar hukum yang meliputi keadilan, kegunaan atau kemanfaatan dan kepastian hukum dapat terwujud guna mencapai kesejahteraan seluruh rakyat Indonesia yang berlandaskan Pancasila dan UUD 1945. ${ }^{9}$

\footnotetext{
8. Barda Nawawi Arif, 2011, Op. Cit, hlm 10.

9. Satjipto Rahardjo, 2014, Imu Hukum, Bandung, PT. Citra Aditya, hlm 19.
} 


\section{Simpulan}

Whistle blower dalam setiap tindak pidana korupsi dan pencucian uang dewasa ini menjadi sangat diperlukan guna mengungkap kejahatan korupsi sebagai extra ordenary crime yang selama ini telah tersistemik dan relatif mengakar di dalam setiap lini birokrasi pemerintahan Negara Indonesia. untuk itu perlu diberikan perlindungan diri pribadi dan keluarganya serta harta kekayaannya sesuai aturan landasan Undang-Undang Dasar Negara RI Tahun 1945 dan Undang-Undang No. 13 Tahun 2006. Kedudukan yang sangat sentral dalam pengungkapan tindak pidana khususnya tindak pidana korupsi ini, menjadi suatu keharusan bagi negara selain memberikan perlindungan secara fisik dan psikis, juga sudah seharusnya memberikan reward atas jasa-jasanya dan keberaniannya untuk mengungkap tindak pidana khususnya tindak pidana korupsi. Seperti yang telah dilakukan oleh negara Korea Selatan.

Kedudukan Whistle blower juga pada hakekatnya dapat menjadi sebuah tolok ukur dalam rangka melakukan pembaharuan hukum yang terkait dengan integralitas atau keterpaduan penegakan hukum pada tataran sistem hukum di bidang substansi hukum material, substansi hukum formal, substasnsi hukum pelaksanaan di Indonesia ini. Dengan melakukan pembaharuan hukum melalui penal policy di bidang hukum pidana, khususnya TPPU dan TP Korupsi, maka selain dilakukan pembaharuan secara substansi hukum pada tataran implementasi dan praksinya.

\section{Daftar Pustaka}

Arief Barda Nawawi, 2001, Masalah Penegakan Hukum dan Kebijakan Penanggulangan Kejahatan, Bandung, PT. Citra Aditya Bakti

Arief Barda Nawawi, 2009, Reformasi Sistem Peradilan (Sistem Penegakan Hukum) di Indonesia, Semarang, Badan Penerbit Universitas Diponegoro.

Halif, "Pencegahan dan Pemberantasan Tindak Pidana Korupsi Melalui Undang-Undang Pencucian Uang”, Jurnal Anti Korupsi PUKAT FHUJ, Vol.2, No. 2, November 2012.
Kusumaatmadja Mochtar, 2002, KonsepKonsep Hukum dalam Pembangunan, Pusat Studi Wawasan Nusantara, Hukum dan Pembangunan, Bandung, PTAlumni.

Rahardjo Satjipto, 2014, Imu Hukum, Bandung, PT. Citra Aditya

Tersedia di website http://www .kompas.com/kompas - cetak/ 0503/01/opini/1592610.htm, diakses pada tanggal 12 Juni 2013

Waluyo Bambang, "Optimalisasi Pemberantasan Kurupsi Di Indonesia", Jurnal Yuridis, Vol. 1, No. 2, Desember 2014, ISSN 1693448.

Kitab Undang-Undang Hukum Pidana.

Kitab Undang-Undang Hukum Acara Pidana.

Undang-Undang Dasar Negara RI Tahun 1945.

Undang-Undang No. 8 Tahun 2010 Tentang Pencegahan Dan Pemberantasan Tindak Pidana Pencucian Uang.

Undang-Undang No. 13 Tahun 2006 Tentang Perlindungan Saksi dan Korban. 